\title{
THE EFFECT OF FEEDING Lactobacillus ON GROWTH, SURVIVAL RATE AND PROTEASE ACTIVITY OF Litopenaeus vannamei
}

\author{
Nunak Nafiqoh*\#, Poh- Shing Chang**), and Yu-Chi Wang ${ }^{* * *}$ \\ *) Research Institute for Freshwater Aquaculture \\ ${ }^{* *}$ National Kaohsiung Marine University, Taiwan, R.O.C \\ ***) I-Shou University, Taiwan, R.O.C
}

(Received 18 July 2011; Accepted 17 September 2011)

\begin{abstract}
This study examined the effect of two Lactobacillus bacteria on protease activity and growth rate of Litopenaeus vannamei. An experiment was conducted to examine protease activity and growth rate. The experiment consisted of two treatment tanks, the first tank was provided with artemia immersed in $2.6 \times 10^{16} \mathrm{cfu} / \mathrm{mL}$ of bacteria solution, the second tank served as the control tank. After 20 days, the L. vannamei in the tank that received Lactobacillus have significantly different in growth, survival rate and protease activity $(\mathrm{P}<0.05)$ compared to the control, but no significant difference between Lactobacillus casei and Lactobacillus plantarum treatments. Within the digestive organ, protease activity of hepatopancreas and stomach demonstrated significant higher activity $(P<0.05)$ compared to the intestine.
\end{abstract}

KEYWORDS: Lactobacillus, growth, survival, protease

\section{INTRODUCTION}

Decreasing of worldwide capture fish production poses a threat on the sustainable supply of fish to support the increasing of food demand. Aquaculture becomes an important aquatic food source to fulfill the ever extending gap of requirement. It is reported that both fresh and sea water aquaculture production increase rapidly. Ministry of Marine Affairs and Fisheries of Republic Indonesia targeted to accelerate aquaculture production.

Four percent of total aquaculture production was contributed from shrimp and prawn (subphylum crustacea) and most of shrimp production was dominated by white leg shrimp Litopenaeus vannamei. Local and international requirements of shrimp production have en- couraged Indonesian farmers to apply intensive aquaculture with high density of initial larvae stocking. This condition has been leading the occurrence of various bacteria and viruses outbreaks to the shrimp farming (Center for Tropical and Subtropical Aquaculture, 1996; Chiu et al., 2006).

Numerous experiments have been conducted in the attempt to solve these problems including food additive application to increase immune and growth responses. For that purpose, live organisms such as microalgae and bacteria have been used in shrimp farming, and these additional substances were known widely as probiotic. Probiotic defined as viable microorganisms that exhibit a beneficial effect on the health of the host upon ingestion (Gomes \& Malcata, 1999).

\# Corresponding author. Research Institute for Freshwater Aquaculture, JI. Sempur No.1, Bogor 16154, West Java, Indonesia. Tel.: + 62251313200

E-mail address: nuna_nafiqoh@yahoo.co.uk 
Probiotic application to enhance the growth performance of fish and shrimp has been studied and the results indicated that probiotic could enhance enzyme activity within the digestive tract of shrimp (Nejad et al., 2006; Wang, 2007; Gomez \& Shen, 2008). Genus of Lactobacillus is widely used as probiotic source due to its well known ability to assist nutrient absorption of the host (Aroutcheva, 2001).

Objective of the present study was to investigate the possibility of lactic acid bacteria as a suitable probiotic for shrimp culture.

\section{MATERIALS AND METHOD}

\section{Experiment}

The experiment was conducted to examine the effect of L. casei and L. plantarum administration. All treatments and control were arranged in triplicates. L. vannamei for the experiment was transported from shrimp farming in Yong- An earthen pond in southern Taiwan, carried in plastic bag and provided with $\mathrm{O}_{2}$ to avoid mortality. Shrimp was fed similar food for three days prior the experiment. The experiment was established in 20 days culture period to determine the effect of treatments on the growth, survival rate and enzyme activity in shrimp digestive organ of L. vannamei. 15 shrimps with $0.1 \mathrm{~g}$ in average were cultured in aerated $45 \mathrm{~cm} \times 15$ $\mathrm{cm} \times 25 \mathrm{~cm}$ glass tank filled with natural sea water (salinity $30 \pm 1 \mathrm{ppt}$ ). Temperature of culture tanks were equivalent with ambient temperature.

\section{Food Source}

Two grams of commercial brine shrimp (Ocean Star International) was cultured in one liter of aerated natural sea water (salinity $30 \pm 1$ ppt) until hatching (approximately 24 hours). Temperature for culturing artemia depends on the ambient temperature. Afterward, hatched artemia was rinse with tap water and immerse for 30 minutes in $1 \mathrm{~mL}$ of bacteria solution. Bacteria Solution was prepared by culturing Lactobacillus in MRS broth, and incubated for 24 hours at $35^{\circ} \mathrm{C}$, resulted in $2.6 \times 10^{16} \mathrm{cfu} / \mathrm{mL}$ of bacteria. Later on, the artemia was immersed in the bacteria solution and fed to the shrimps. Artemia as food source for shrimp was prepared freshly every feeding time.

\section{Sampling}

Shrimp was counted and measured individually at the beginning of the experiment (Day 0) and at the end of the experiment (Day $20)$ to determine the survival rate and average of daily weight gain. The Survival Rate (SR; \%) was calculated as;

$$
\frac{\text { Final amount }}{\text { Intial amount }} \times 100 \%
$$

And average of daily weight gain (DWG; $\mathrm{gd}^{-1}$ ) was calculated as;

$$
\text { Final weight (g) - Initial weight (g) }
$$$$
20 \text { days }
$$

For further assay, three shrimps were collected in day 0 of the experiment and another three shrimps in day 20 of the experiment and used to determine the protease activity.

\section{Protease Activity}

The collected shrimps from day 0 samples were homogenized; whereas samples from day 20 were prepared by dissecting its digestive organ. Samples were collected two hours after feeding time from each tank, measured and then stored at $-70^{\circ} \mathrm{C}$ until assay process. Samples were homogenized with chilled 9 volumes of Tris (hydroxy methyl) aminomethane hydrochloride (Tris- $\mathrm{HCl}$ ) buffer in microfuge tube, then centrifuged at 7,000 xg for 20 minutes at $4^{\circ} \mathrm{C}$ (Lovett \& Felder, 1990) with modification. In all treatment preparation steps, temperature was maintained at $4^{\circ} \mathrm{C}$ to avoid enzyme activation.

Protein assay procedures used $100 \mu \mathrm{L}$ of sample supernatant mixed in $100 \mu \mathrm{L}$ azocasein substrate. The mixture was allowed to stand for 20 minutes at $60^{\circ} \mathrm{C}$. The reaction was stopped by adding $20 \mu \mathrm{L}$ of Trichloroacetic acid solution. It was then centrifuged for 15 minutes at $12,000 \mathrm{rpm}$ to pellet the substrate crude. The supernatant was poured into new microfuge tube and added with $700 \mu \mathrm{L}$ of 525 $\mathrm{mN}$ Sodium hydroxide solution, followed by measure at $420 \mathrm{~nm}$ spectrophotometer, 1 unit/ $\mathrm{mL}$ was determine as 0.01 OD change (Park et al., 2003). 
The effect of feeding Lactobacillus on growth, ... (Nunak Nafiqoh)

\section{RESULTS AND DISCUSSION}

After 20 days culture, the treatment tank showed significant difference $(\mathrm{P}<0.05)$ compared to the control tank. For survival rate, both treatment groups were significantly different compared to the control (Table 1).

Weight gains were present in all groups after 20 days culture period, and the treatment group has a significant better growth performance $(P<0.05)$ compared to the control group. This result was similar with several previous experiments where application of probiotic treatment produced better body weight gain. Suzer et al. (2008) administered Lactobacillus to the sea bream and the result showed that the growth of the experiment group reached $0.5 \%$ higher compared to the control group. Another experiment using bacillus as probiotic for Penaeus vannamei showed that the experiment group had $0.3 \%$ higher growth rate compared to the control group (Wang, 2007).

Better growth performance after probiotic administration might be caused by probiotic that has the ability to induce the digestive enzyme activity and facilitate digestion of all protein constituents. Since penaeid crustaceans can adapt very well on any changes of the diet composition by induction of digestive enzymes synthesized and secreted in the hepatopancreas. These digestive enzymes are able to hydrolyze a variety of substrates, and various factors are involved in their regulation, including stimulant effect such probiotic (Le Moullac et al., 1997; Moss et al., 2001).

Probiotic bacteria was also claimed to be able to produce enzymes that can complete the shrimp protease activity in increasing food digestibility. In addition, the probiotic enzymes have a broader $\mathrm{pH}$ range than the shrimp enzymes. This would prolong the digestion time of the host. Unfortunately, it is nearly impossible to distinguish between enzyme synthesized by the shrimp or enzyme synthesized by probiotic (Wang, 2007; Nejad et al., 2006; Solano \& Soto, 2006).

Survival rate result showed a higher survival rate in both treatments compared to the control. It is already described in the previous experiment published by Rengpipat et al. (1998) and Balcázar et al. (2007), these experiments mentioned that an administration of probiotic was able to increase the survival rate of the host. Increasing of the survival rate was influenced by alteration of the microbial community. The alteration triggers a process to exclude pathogen bacteria within the host, which is the common aim of probiotic administration. Another benefit of administering probiotic host is antibacterial substances which are produced by probiotic. It can increase immune response in the gastrointestinal system. The gastrointestinal system of animals is important organ, since it has a direct contact with absorbed nutrient and the environment (Gullian et al., 2003; Salinas et al., 2005).

Anti bacterial activity of L. plantarum and L. casei were described to have the ability to inhibit the growth of various bacteria. L. plantarum produced antibacterial substances characterized as a bacteriocin and was designated plantaricin. This bacteriocin was purified and identified by Todorov et al. (1998). They found this antimicrobial substance is a peptide of 20 amino acid residues with a mass of $2,755 \pm 0.3 \mathrm{Da}$. Antimicrobial activity of this substance also found to have the widest range of inhibition spectrum. The bacterocin was produced by $L$. plantarum during the late logarithmic growth phase at a cell count of $1.5 \mathrm{x}$ $10^{9} \mathrm{cfu} / \mathrm{mL}$. L. plantarum administration to the

Table 1. The effect of Lactobacillus treatment on the growth performance and survival rate of L. vannamei. DWG: Daily Weight Gain; SR: Survival Rate. Result was presented as mean \pm S.E. Means in the same row with different superscripts are significantly different $(\mathrm{P}<0.05)$

\begin{tabular}{lccc}
\hline & L. casei & L. plantarum & Control \\
\hline Initial weight $(\mathrm{g})$ & $0.10 \pm 0.01^{\mathrm{a}}$ & $0.10 \pm 0.01^{\mathrm{a}}$ & $0.10 \pm 0.01^{\mathrm{a}}$ \\
Final weight $(\mathrm{g})$ & $1.11 \pm 0.01^{\mathrm{b}}$ & $1.10 \pm 0.02^{\mathrm{b}}$ & $0.73 \pm 0.04^{\mathrm{a}}$ \\
DWG $\left(\mathrm{g} \cdot \mathrm{d}^{-1}\right)$ & $0.051 \pm 0.001^{\mathrm{b}}$ & $0.05 \pm 0.001^{\mathrm{b}}$ & $0.032 \pm 0.002^{\mathrm{a}}$ \\
SR $(\%)$ & $100 \pm 0^{\mathrm{a}}$ & $100 \pm 0^{\mathrm{a}}$ & $91.1 \pm 0.58^{\mathrm{b}}$ \\
\hline
\end{tabular}


cultured aquatic animals showed increasing of immune response of the animal against bacterial pathogen (Messi et al., 2001; Chiu et al., 2007).

Antibacterial produced by L. casei is characterized as bacteriocin caseicin 80 , a thermolabile protein with a molar mass of $42 \mathrm{kDa}$ (Muller \& Radler, 1993). Bacteriocin is assumed to prevent bacteria development, especially pathogenic bacteria from overgrowing and has the ability to inhibit other bacteria and also able to stimulate the immune systems (Voravutikunchai et al., 2006; Aroutcheva et al., 2001). Application to the aquatic organism resulted in the increase of immune response against both gram- negative and gram- positive fish pathogens by the acid production (Ma et al., 2009; Aly et al., 2008).

There is no significant difference among treatments in day 0 . After 20 days of culture, protease activity of the treatment groups was significantly higher $(P<0.05)$ than that of the control group, although no difference was observed between treatment groups (Figure 1a). The protease activity within intestine was significantly lower $(P<0.05)$ among organs in the treatment groups and the control group (Figure 1b).

The treatment group was significantly higher in protease activity compared to the control group. It is arguably concluded that a protein was responsible in increasing the growth of penaeid crustacean (Kureshy \& Davis, 2002). Soluble protein has a correlation with the body weight increase; although the protease activity will decrease following the

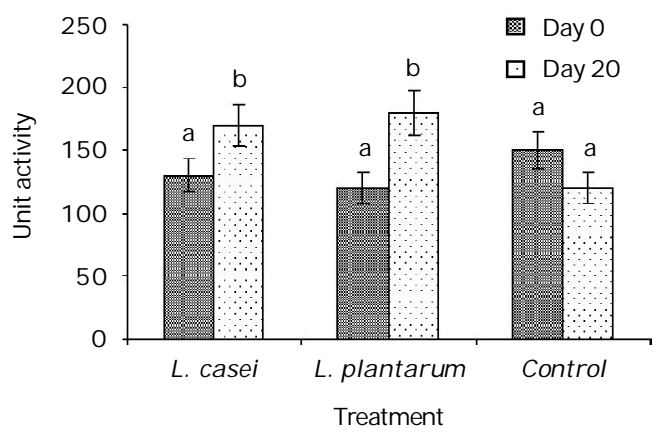

increase of the weight as a result of the decrease ability of the shrimp to use protein as food source (Lee et al., 1984; Delgado et al., 2003).

Probiotic addition to the food was triggering the effectiveness of nutrition absorption. Although the mechanism of probiotic action is poorly understood, but some experiments already revealed that $L$. casei and $L$. plantarum produce proteolytic enzyme in low amount (IZtaliou et al., 1996; Ong et al., 2007), this is in line with the different result between the present study which used Lactobacillus bacteria as the probiotic substance and the previous study which used Bacillus as the probiotic material which has high amount of protease activity (Wang, 2007; Gómez \& Shen, 2008).

L. casei is capable to synthesize all but the branched- chain amino acids. It is equipped with proteolytic enzyme system that allows it to acquire amino acids from proteins. Analysis of the proteolytic enzyme system in Lactic Acid Bacteria (LAB) has shown that enzymes involved in procurement of amino acids from caseins can be divided into three major categories; one of the three categories is an extracellular cell surface associated proteinase, termed lactocepin that hydrolyzes casein into oligopepteides. L. casei genome contains three CDS for lactocepin (LSEI_0465, 0468, and 2270). Lactocepins are synthesized as an inactive precursor and some require a membrane- bound lipoprotein (PrtM) (Cai, 2009).

While L. plantarum genome does not appear to encode the primary enzyme required for large polypeptide utilization of Prt (extra-

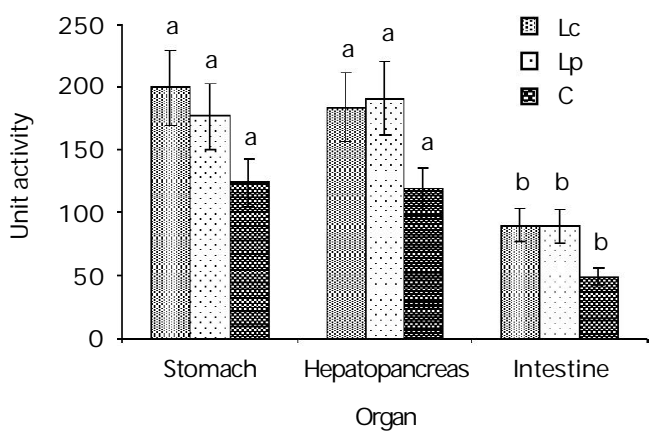

Figure 1. The effect of Lactobacillus treatment on protease activity; (a) day 0 and day 20, (b) digestive organ. Lc: L. casei treatment group; Lp: L. plantarum treatment group; C: Control group. Means with different superscript are significantly different; first letter compares protease activity between organs in one treatment group, second letter compares protease activity between treatment groups in different organ $(P<0.05)$ 
cellular protease). However, L. plantarum has uptake systems (Opp and Dtp) for peptides, which are the primary protein degradation product (Kleerebezem et al., 2003).

The result also shows higher protease activity in the stomach and hepatopancreas of the shrimp compare to the intestine. It was due to the primary function of both stomach and hepatopancreas in the food processing, whereas the intestine serves only as a canal to excrete food residues. In teleost fish, high number of digestive enzyme was detected in hindgut part of digestion system compared to foregut part. Hindgut part of teleost fish digestive system consists of stomach, intestine, and pyloric caeca. Those organs are functioned to break down (digest) food and absorb nutrients. Piscivorous fishes have fairly short intestines because their diet is easy to be chemically broke down while herbivorous fishes require longer intestines because plant matter is usually tough and fibrous so that it is more difficult to break down into usable components.

Pyloric caeca is located near the junction of the stomach and the intestines. Its function is not entirely understood, but it is known to secrete enzymes that aid in digestion processes such as to absorb digested food (Hoar \& Randall, 1988).

Stomach is the first organ encountered by food in digestion system. Food enters the stomach then pass through the gastric mill before entering the pyloric pocket. The food is returned to pass through the system again after processed by lateral outgrowths (teeth and ossicles). The liquid phase flows antero- posteriorly along ventro- lateral sides leading to the principal channels of the pyloric pocket excluding any particles larger than $1 \mathrm{~nm}$. These non digestible particles are rejected into the hindgut. By this mechanism, it is possible that chemical digestion begins in the stomach to help to reduce the size of the particles. Here, enzyme might be secreted in the stomach (Ceccaldi, 1989).

Hepatopancreas takes the central role in metabolic processes. It is responsible for the synthesis and secretion of digestive enzymes. It also functions during uptake nutrients, storaging of inorganic reserves and lipid and carbohydrate metabolism (Correia et al., 2002). The function of hepatopancreas is assisted by R-cell and F- cell. R-cell absorbs luminal nutrients, mainly via contact digestion and molecular transport. R- cell also stores and metabolizes glycogen and lipids. F-cell synthesizes digestive enzyme and excreted the enzymes in supranuclear vacuole which enlarges by pinocytic intake of luminal nutrients and fluids (Loizzi, 1970).

\section{CONCLUSION}

- Lactobacillus plantarum and L. Casei are the viable option of probiotic to improve the growth and survival rate of Litopenaeus vannamei.

- There is no significant difference on the growth performance as well as survival rate of tested shrimp between the treatments of Lactobacillus plantarum and L. Casei.

\section{ACKNOWLEGMENT}

This study was carried out under the support of the National Kaohsiung Marine University and funded by Master Program Research Fund. The author would like to thank to Prof. Poh- Shing Chang, Prof. Wen- min Chen, Yu- Chi Wang, P.hD., and all my colleagues for their help during experiment. Sincere thanks is also addressed to Dr. Rudhy Gustiano, the head of RIFA (Research Institute for Freshwater Aquaculture) for his comment and suggestion.

\section{REFERENCES}

Aly, S.M., Ahmed, Y.A.G., Ghareeb, A.A.A., \& Mohamed, M.F. 2008. Studies on Bacillus subtilis and Lactobacillus acidophilus, as potential probiotics, on the immune response and resistance of Tilapia nilotica (Oreochromis niloticus) to challenge infections. Fish \& Shellfish Immunology, 25: 128136.

Aroutcheva, A.A., Simoes, J.A., \& Faro, S. 2001. Antimicrobial protein produced by vaginal Lactobacillus acidophilus that inhibits Gardnerella vaginalis. Infect Dis Obstet Gynecol., 9: 33- 39.

Balcázar, J.L., Rojas- Luna, T., \& Cunningham, D.P. 2007. Effect of the addition of four potential probiotic strains on the survival of pacific white shrimp (Litopenaeus vannamei) following immersion challenge with Vibrio parahaemolyticus. J. of Invertebrate Pathology, 96: 147- 150.

Cai, H., Thompson, R., Budinich, M.F., Broadbent, J.R., \& Steele, J.L. 2009. Genome sequence and comparative analysis insight into their 
niche- associated evolution. Research article. Genome biology and evolution.

Ceccaldi, H.J. 1989. Anatomy and physiology of digestive tract of Crustaceans Decapods reared in aquaculture. Advances in tropical aquaculture. Aquacop. IFREMER. Actes de Colloque, 9: 243- 259.

Center for Tropical and Subtropical Aquaculture The Oceanic Institute. 1996. Shrimp Diseases. CTSA Publication. No. 121. Hawaii.

Chiu- Hsia Chiu, Yuan- Kuang Guu, Chun- Hung Liu, Tzu- Ming Pan, \& Winton Cheng. 2007. Immune responses and gene expression in white shrimp, Litopenaeus vannamei, induced by Lactobacillus plantarum. Fish \&Shellfish Immunology, 23: 364- 377.

Correia, A.D., Pereira, A.L., Costa, M.H., \& Carrapiço, F. 2002. Functional anatomy of the midgut gland of Gammarus locusta (Crustacea : Amphipoda). J. Mar. Biol. Ass. U.K., 82: 201- 204.

Delgado, J.G., César Molina- poveda1, \&Chantal Cahu. 2003. Digestive enzyme activity and food ingesta in juvenile shrimp Litopenaeus vannamei (Boone, 1931) as a function of body weight. Aquaculture Research, 34(15): 1,403-1,411.

Food and Agriculture Organization; Aquaculture Production Statistic. 2010. Available at www. FAO.org.

Hoar, W.S. \& Randall, D.J. 1988. Fish physiology. Academic Press. New York.

Gomes, A. \&Malcata, F.X. 1999. Bifidobacterium spp. and Lactobacillus acidophilus biological, biochemical, technological and therapeutical properties relevant for use as probiotics. Trends in Food Science and Technology, 10: 139- 157.

Gómez, R.G.D. \& Shen, M.A. 2008. Influence Of Probiotics On The Growth And Digestive Enzyme Activity Of White Pacific Shrimp (Litopenaeus vannamei). J. Ocean. Univ. China, 7: 215-218.

Gullian, M., Thompson, F., \& Rodriguez, J. 2003. Selection of probiotic bacteria and study of their immunostimulatory effect in Penaeus vannamei. Aquaculture, 233: 1- 14.

Kleerebezem, M., Boekhorst, J., van Kranenburg, R., Molenaar, D., Kuipers, O.P., Leer, R., Tarchini, R., Peters, S.A., Sandbrink, H.M., Fiers, M.W.E.J., Stiekema, W., Klein Lankhorst, R.M., Bron, P.A., Hoffer, S.M., Nierop Groot, M.N., Kerkhoven, R., de Vries, M., Ursing, B., de Vos, W.M., \& Siezen, R.J.
2003. Complete genome sequence of Lactobacillus plantarum WCFS1. Proceed Natl Acad of USA, 100(4): 1,990- 1,995.

Kureshy, N. \&Davis, D.A. 2002. Protein requirement for maintenance and maximum weight gain for the pacific white shrimp, Litopenaeus vannamei. Aquaculture, 204: 125- 143.

Lee, P.G., Smith, L.L., \& Lawrence, A.L. 1984. Digestive proteases of Penaeus vannamei Boone: relationship between enzyme activity, size and diet. Aquaculture, 42: 225239.

Le Moullac, G., Klein, B., Sellos, D., \& Van Wormhoudt, A. 1997. Adaptation of trypsin, chymotrypsin and a- amylase to casein level and protein source in Penaeus vannamei (Crustacea Decapoda). J. of Exp. Mar. Biol. and Ecol., 208: 107- 125.

Loizzi, R.F. 1970. Interpretation of crayfish hepatopancreatic function based on fine structural analysis of epithelial cell lines and muscle network. Zellforsch, 113: 420440.

Ma, C.W., Cho, Y.S., \& Oh, K.H. 2009. Removal of pathogenic bacteria and nitrogens by Lactobacillus spp. JK- 8 and JK- 11. Aquaculture, 287: 266- 270.

Messi, P., Bondi, M., Sabia, C., Battini, R., \& Manicardi, G. 2001. Detection and preliminary characterization of a bacteriocin (plantaricin 35d) produced by a Lactobacillus plantarum strain. Short communication. International J. of Food Microbiology, 64: 193- 198.

Moss, S.M., Divakaran, S., \& Kim, B.G. 2001. Stimulating effects of pond water on digestive enzyme activity in the pacific white shrimp Litopenaeus vannamei (Boone). Aquaculture Research, 32: 125- 131.

Muller, E. \& Radler, F. 1993. Caseici, a Bacteriocin from Lactobacillus casei. Folia Microbial., 38(6): 441- 446.

Nejad Ziaei et al. 2006. The Effect Of Bacillus spp. Bacteria Used As Probiotics On Digestive Enzyme Activity, Survival And Growth In The Indian White Shrimp Fenneropenaeus indicus. Aquaculture, 252: 516- 524.

Ong, L., Henrikson, A., \&Shah, N.P. 2007. Proteolytic pattern and organic acid profiles of probiotic cheddar cheese as influenced by probiotic strain of Lactobacillus acidophilus, L. paracasei, L. casei, or Bifidobacterium sp. Intl Dairy J., 17: 6778. 
In Jae Park, I.J., Yoon, J.C., Park, S.J., Ho Kim, E., Cho, Y.J., \& Soo Shin, K. 2003. Characterization of the Proteolytic Activity of Bacteria Isolated from a Rotating Biological Contactor. The J. of Microbiology, 41(2): 7377.

Wang, Y.B. 2007. Effect Of Probiotics On Growth Performance And Digestive Enzyme Activity Of The Shrimp Penaeus vannamei. Aquaculture, 269: 259- 264.

Rengpipat, S., Phianphak, W., Piyatiratitivorakul, S., \& Menasveta, P. 1998. Effect of a probiotic bacterium on black tiger shrimp Penaeus monodon survival and growth. Aquaculture, 167: 301- 313.

Solano, J.L.O. \& Soto, J.O. 2006. The functional property of Bacillus for shrimp feeds. Food Microbiol., 23: 519- 525.

Salinas, I., Cuesta, A., Ángeles Esteban, M., \& Meseguer, J. 2005. Dietary administration of Lactobacillus delbrüeckii and Bacillus subtilis, single or combined, on gilthead seabream cellular innate immune responses. Fish \& Shellfish Immunology, 19: 67-77.

Todorov, S., Onnob, B., Sorokinec, O., Chobertd, J.M., Ivanovaa, I., \& Dousset, X. 1998. Detection and characterization of a novel antibacterial substance produced by Lactobacillus plantarum ST 31 isolated from sourdough. International J. of Food Microbiology, 48 :167- 177.

Voravuthikunchai, S.P., Bilasoia, S., \& Supamala, O. 2006. Antagonistic activity against pathogenic bacteria by human vaginal lactobacilli. Anaerobe, 12: 221- 226.

IZtaliou, E., Tsakalidou, Tzanetakis, N., \& Kalantzopoulos, G. 1996. Lactobacillus plantarum strain isolated from traditional Greek cheese Taxonomic characterization and screening for enzyme activities. Intl. Ddairy J., 76: 209- 216. 